\title{
Oxygen Uptake and Nitrification by Soil Within a Grazed Atriplex vesicaria Community in Semiarid Rangeland
}

\author{
A. J. RIXON 1,2 \\ Senior Research Scientist, Riverina Laboratory, Division of Plant Industry, \\ C.S.I.R.O., Deniliquin, New South Wales, 2710, Australia.
}

\section{Highlight}

The effect of plant distribution on oxygen uptake and nitrification in surface soil of a semiarid rangeland community was studied. Oxygen uptake and nitrification in surface $(0-7.5 \mathrm{~cm})$ soils from sites associated with Atriplex vesicaria bushes were at least twice as great as in soils from the interbush area. The pattern of nutrient cycling tended to reflect the distribution of plant matcrial within the plant community. The effect did not extend to the $7.5-15 \mathrm{~cm}$ soil horizon.

The rate of nitrification per unit total soil nitrogen was greater for the sites associated with saltbush than for the interbush area. These differences in rate of nitrification per unit total nitrogen persisted for at least two years following the total elimination of saltbush (Atriplex vesicaria) by heavy grazing.

Saltbush (Atriplex vesicaria) communities are examples of areas of spaced perennial bushes in semiarid rangeland (Branson, Miller, and McQueen, 1967). Within these communities, plant distribution is patterned in space and in time (Osborn, Wood, and Paltridge, 1932); the perennials, chiefly $A$. vesicaria maintain a spatial continuity, while numerous annual plants are seasonally present or absent. Very little is known about the cycling of plant nutrients in arid regions nor about the effects of plant distribution in communities on this process (Ross, 1969).

Grazing intensity can drastically affect components of semiarid rangeland. An insignificant change in saltbush ( $A$. vesicaria) occurred

\footnotetext{
${ }^{1}$ Present position is Senior Lecturer, Department of Civil and Agricultural Engineering, Queensland Institute of Technology, Darling Downs, Toowoomba, QueensIand, Australia.

2 Thanks are due to Mr. G. A. McIntyre, Division of Mathematical Statistics, C.S.I.R.O., for helpful advice with statistical analysis of the data, Dr. J. K. Marshall of the Riverina Laboratory for help and advice in obtaining the soil temperature data, and the staff of the chemistry laboratory of the Riverina Laboratory for the total nitrogen determinations. The able technical assistance of Miss C. M. Melville is gratefully acknowledged.
}

with 0.6 sheep per hectare $(0.25$ sheep/acre) over a thrcc ycar period according to Wilson, Leigh, and Mulham (1969); however, at 2.5 sheep per hectare (1.0 sheep/acre) saltbush was virtually eliminated from the rangeland. The removal of saltbush may be expected to affect rangeland plant production, accumulation of organic matter, and the habitat of some organisms contributing to the decomposer cycle, and may lead to significant modifications in the cycling of nutrients.

Mineralization of organic carbon is necessary in order to achieve net mineralization of nitrogen in soil. Since the production of carbon dioxide through microbial respiration approximates oxygen uptake at moisture tensions of $100 \mathrm{~cm}$ or greater (Rixon, 1968), the measurement of oxygen uptake provides an appropriate estimate of this activity at these moisture tensions.

This paper presents information on the variations in oxygen uptake and nitrification with two sites within $A$. vesicaria communities managed at two grazing intensities.

\section{Materials and Methods}

Field Site and Collection of Material

Soil samples, used in this investigation, were collected from an area of semiarid rangeland located 51 kilometres (32 miles) north of Dcniliquin, New South Wales. The mean annual rainfall is $38 \mathrm{~cm}(15$ inches) occurring mainly in winter. The soil type is Billabong clay, a brown soil of heavy texture (Smith, 1945). The area is virtually flat.

The soil samples were collected from two adjacent areas within a grazing experiment (Wilson, Leigh, and Mulham, 1969). One area had been stocked at 0.6 sheep per hectare for 3 years and this is designated as lightly grazed. The other area had been stocked at 2.5 sheep per hectare for 3 years and this is designated as heavily grazed. The grazing experiment had been terminated about 2 years previously, and there had been no further grazing by sheep on the experimental area.

On the lightly grazed plot, the saltbushes were $20-40 \mathrm{~cm}$ high, and were about $50 \mathrm{~cm}$ across. They were spaced about 1.5-2 m apart. Several annual and perennial plants, including various composites and some grasses, grew between the bushes, and to some extent on the areas formerly occupied by bushes on the heavily grazed plots. The main annual growth in such communities occurs in winter and spring, and much of this remains during the summer as erect dry stubble. An indication of the variety of plant species, botanical composition, and distribution of plant material within the saltbush community from the lightly grazed area is shown in Table 1 (lb./acre = $1.121 \mathrm{~kg} / \mathrm{ha}$ ).

After three years, grazing had eliminated virtually all the saltbush from the rangeland at 2.5 sheep per hectare. However, the sites where the saltbush formerly grew were clearly defined at the time of sampling in 1969, two years after the grazing trial had been terminated.

Soil samples were collected in February 1969 (summer) from two adjacent experimental plots represcntative of the heavily grazed and lightly grazed treatments. Four replicate samples were collected from 
Table 1. Weight ${ }^{1}(\mathrm{~kg} / \mathrm{ha})$ plant material harvested in September 1969 from an Atriplex vesicaria community of the Riverine Plain of southeastern Australia.

\begin{tabular}{|c|c|c|}
\hline \multirow[b]{2}{*}{ Family } & \multicolumn{2}{|c|}{$\begin{array}{l}\text { Issociated with } \\
\text { triplex vesicuria Between }\end{array}$} \\
\hline & bushes & bushes \\
\hline \multicolumn{3}{|l|}{ Chenopodiaceae } \\
\hline Atriplex sp. & 7720 & 0 \\
\hline Kochia & 0 & 6 \\
\hline Leguminosae & 1313 & 324 \\
\hline Compositae & 155 & 86 \\
\hline Gramineae & 47 & 21 \\
\hline Crassulaceae & 2 & 0 \\
\hline Plantaginaceae & 5 & 52 \\
\hline Goodenaceae & 2 & 7 \\
\hline Total & 9244 & 496 \\
\hline Litter & 2390 & 660 \\
\hline
\end{tabular}

1 Mean of 5 replicates.

under saltbush, or where saltbush formerly grew, and from the interbush areas. The samples were obtained from sites approximately 10 $\mathrm{m}$ apart and each consisted of 10 cores of diameter $4.4 \mathrm{~cm}$ sampled to a depth of $7.5 \mathrm{~cm}$.

Further soil samples were collected at $0-7.5 \mathrm{~cm}$ and $7.5-15 \mathrm{~cm}$ depths from the lightly grazed area in July 1969 (winter), four each from under saltbush and from adjacent areas between saltbush. Differences in amount of oxygen uptake by the soils (collected in winter) due to depth and site within the plant community, as well as all comparisons for rates of oxygen uptake and of nitrification were analysed statistically with a " $t$ " test.

\section{Soil Preparation and Methods of Analysis}

The soil samples were air-dried, and then ground with a mechanical grinder to pass through a $2 \mathrm{~mm}$ sieve. The moisture content of the ground soil at $100 \mathrm{~cm}$ was determined on a suction plate.

Oxygen uptake.-Soil samples from the two sites within the plant community from the two grazing treatments were air-dried, moistened, and oxygen uptake was measured over the subsequent ten days for soils collected in February, and seven days for soils collected in July. Samples of $100 \mathrm{~g}$ of soil were brought to $100 \mathrm{~cm}$ moisture tension by adding the required amount of distilled water, using an atomizer and constant stirring to ensure uniform wetting. The respiring samples were placed in electrolytic respirometers, which replace oxygen in the sample flask as it is used, and oxygen uptake measured over a period of several days (Birch and Melville, 1969).

Mineral nitrogen.-Samples of 10 $g$ of soil were extracted after shaking on an end over end shaker for 30 minutes with $40 \mathrm{ml}$ of $1 \mathrm{~N} \mathrm{KCl}$. Mineral nitrogen was determined by the steam distillation method of Bremner and Keeney (1965) on airdry samples, and on samples after the period in the respirometer. The amount of ammonium did not exceed 5 ppm for any of the soils, and consequently is not reported.

Total nitrogen was determined by a Kjeldahl method using selenium as catalyst. Organic carbon

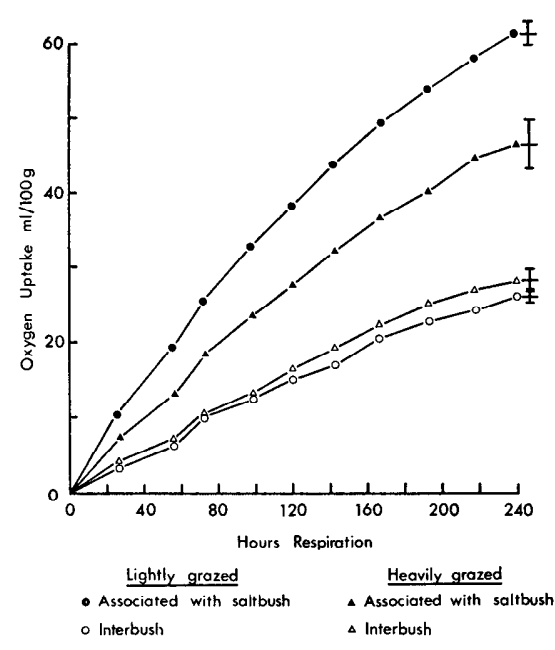

FIG. 1. Effect of grazing intensity on oxygen uptake by soil from two sites within saltbush rangeland.

was determined in a combustion furnace (Piper, 1942).

The soil $\mathrm{pH}$ values were obtained with a glass electrode calomel electrode assembly on a 1:5 soil-water suspension.

\section{Results}

The percentage total nitrogen and organic carbon in the soil samples are shown in Table 2. The $\mathrm{pH}$ of the $0-7.5 \mathrm{~cm}$ layer was 7.3 , and of the $7.5-15 \mathrm{~cm}$ layer was 7.6 , with no differences between sites.

\section{Oxygen Uptake}

Oxygen uptake was much greater by the soil associated with saltbush than by the soil from the interbush areas (Fig. 1). Heavy grazing markedly decreased oxygen uptake by soil previously associated with salt-

Table 2. Mean values (\%) for organic carbon and total nitrogen of soil at two sites within the saltbush rangeland grazed at two intensities, and at two depths in lightly grazed saltbush rangeland.

\begin{tabular}{|c|c|c|c|c|c|}
\hline \multirow[b]{2}{*}{$\begin{array}{l}\text { Grazing } \\
\text { intensity }\end{array}$} & \multirow[b]{2}{*}{ Depth } & \multicolumn{2}{|c|}{ Associated with saltbush } & \multicolumn{2}{|c|}{ Interbush area } \\
\hline & & C & $\mathrm{N}$ & C & $\mathrm{N}$ \\
\hline Lightly grazed $^{1}$ & $0-7.5 \mathrm{~cm}$ & $1.224 \pm 0.055^{3}$ & $0.119 \pm 0.013$ & $0.767 \pm 0.045$ & $0.086 \pm 0.009$ \\
\hline Heavily grazed ${ }^{2}$ & $0-7.5 \mathrm{~cm}$ & $1.060 \pm 0.030$ & $0.118 \pm 0.013$ & $0.712 \pm 0.060$ & $0.091 \pm 0.008$ \\
\hline Lightly grazed 1 & $0-7.5 \mathrm{~cm}$ & $1.218 \pm 0.055$ & $0.126 \pm 0.011$ & $0.833 \pm 0.038$ & $0.093 \pm 0.010$ \\
\hline Lightly grazed ${ }^{1}$ & $7.5-15 \mathrm{~cm}$ & $0.707 \pm 0.042$ & $0.086 \pm 0.003$ & $0.550 \pm 0.032$ & $0.068 \pm 0.004$ \\
\hline
\end{tabular}

1 Experimental areas stocked at 0.6 sheep per hectare for 3 years.

2 Experimental areas stocked at 2.5 sheep per hectare for 3 years.

3 Standard error. 


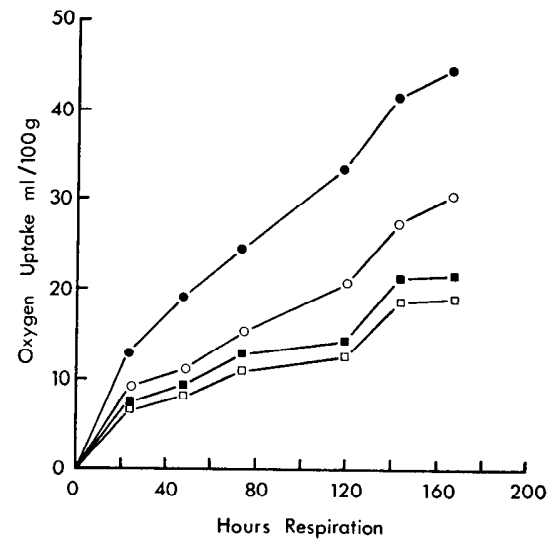

- $0-7.5 \mathrm{~cm}$ Associated with saltbush

$0=7.5 \mathrm{~cm}$ Interbush

- 7.5-15 cm Associated with saltbush

- $7.5-15 \mathrm{~cm}$ Interbush

Fig. 2. Oxygen uptake by soil from two depths at two sites within lightly grazed saltbush rangeland.

bush, but had only a slight effect on oxygen uptake by the soil from between saltbushes.

Oxygen uptake of soil sampled in winter at $0-7.5 \mathrm{~cm}$ and $7.5-15 \mathrm{~cm}$ depths from the lightly grazed area is shown in Figure 2. Oxygen uptake by the $0-7.5 \mathrm{~cm}$ soil from under saltbush was again much greater $(\mathbf{P}<0.01)$ than by soil from between saltbush. There was no
Table 4. Nitrate levels (ppm nitrate $\mathbf{N}$ ) in air-dry and incubated soils collected at two sites within saltbush rangeland grazed at two intensities, and at two depths in lightly grazed saltbush rangeland.

Grazing

intensity

and site

Air dry

After respiration

Increase

Lightly grazed ${ }^{1}$

Associated with saltbush

Interbush

$8.4 \pm 0.8^{3}$

$29.3 \pm 2.7$

$20.9 \pm 4.8$

$7.4 \pm 1.3$

$8.1 \pm 0.2$

$0.7 \pm 1.9$

Heavily grazed ${ }^{2}$

Associated with saltbush

Interbush

$18.3 \pm 0.5$

$35.2 \pm 2.2$

$16.9 \pm 3.8$

$5.6 \pm 1.3$

$9.4 \pm 1.1$

$3.8 \pm 0.5$

Lightly grazed 1 $0-7.5 \mathrm{~cm}$

Associated with saltbush Interbush

$\begin{array}{llr}6.3 \pm 0.6 & 20.5 \pm 0.4 & 14.2 \pm 1.0 \\ 6.3 \pm 0.7 & 13.8 \pm 1.8 & 7.5 \pm 1.6\end{array}$

Lightly grazed ${ }^{1}$

$7.5-15 \mathrm{~cm}$

Associated with saltbush

$4.2 \pm 1.0$

$10.5 \pm 0.6$

$6.3 \pm 1.3$

Interbush

$3.2 \pm 2.0$

$6.2+0.5$

$3.0+2.1$

1 Experimental areas stocked at 0.6 sheep per hectare for 3 years

2 Experimental areas stocked at 2.5 sheep per hectare for 3 years.

3 Standard error.

significant difference due to site for oxygen uptake at the $7.5-15 \mathrm{~cm}$ soil horizon.

The rate of oxygen uptake per unit quantity of organic carbon per ten hours is shown in Table 3 . The rate of oxygen uptake by soil from lightly grazed saltbush rangeland

Table 3. Rates ( $\mathrm{ml}$ ) of oxygen uptake per gram of organic carbon per ten hours by soils from two sites within saltbush rangeland grazed at two intensities, and from two depths at two sites within lightly grazed rangeland.

\begin{tabular}{lccccc}
\hline \hline $\begin{array}{c}\text { Grazing } \\
\text { intensity }\end{array}$ & Depth & $\begin{array}{c}\text { Asso- } \\
\text { ciated } \\
\text { with } \\
\text { bush }\end{array}$ & $\begin{array}{c}\text { Inter- } \\
\text { bush }\end{array}$ & $\begin{array}{c}\text { Differ- } \\
\text { ence }\end{array}$ & $\begin{array}{c}\text { Signifi- } \\
\text { cance of } \\
\text { differ- } \\
\text { ence }\end{array}$ \\
\hline $\begin{array}{l}\text { Heavily grazed } \\
\quad \text { (collected in summer) }\end{array}$ & $0-7.5 \mathrm{~cm}$ & 1.82 & 1.68 & 0.14 & N.S. \\
$\begin{array}{l}\text { Lightly grazed } \\
\quad \text { (collected in summer) }\end{array}$ & $0-7.5 \mathrm{~cm}$ & 2.08 & 1.41 & 0.67 & $* *$ \\
$\begin{array}{l}\text { Difference } \\
\text { Signif. of Difference }\end{array}$ & $0-7.5 \mathrm{~cm}$ & 2.17 & 2.18 & 0.01 & N.S. \\
$\begin{array}{l}\text { Lightly grazed } \\
\quad \text { (collected in winter) }\end{array}$ & $7.5-15 \mathrm{~cm}$ & 1.82 & 2.02 & 0.20 & N.S. \\
$\begin{array}{l}\text { Lightly grazed } \\
\text { (collected in winter) }\end{array}$ & & 0.26 & 0.27 & & \\
$\begin{array}{l}\text { Difference } \\
\text { Signif. of Difference }\end{array}$ & & 0.35 & 0.16 & & \\
\hline
\end{tabular}

${ }^{1}$ Experimental areas stocked at 2.5 sheep per hectare for 3 years.

2 Experimental areas stocked at 0.6 sheep per hectare for 3 years.

$3 * *=\mathbf{P}<0.01$

differed for the two sites in the summer, but not in the winter. There were no differences in rate of oxygen uptake at the two sites within heavily grazed saltbush rangeland. The rate of oxygen uptake decreased with depth under saltbush, but not for interbush areas.

\section{Nitrification}

The changes in nitrate in the soil samples from the grazing treatments, and from two depths at two sites within the lightly grazed saltbush rangeland are shown in Table 4. There was a much greater increase in nitrate in the incubated soil from sites associated with saltbush than for soil from the interbush area. This relationship was consistent for the two grazing intensities, but was confined to the $0-7.5 \mathrm{~cm}$ soil horizon. Heavy grazing resulted in an increase in nitrate in the soil associated with saltbush.

The rates of production of nitrate per unit total soil nitrogen per ten hours by soils from two sites within saltbush rangeland grazed at two intensities, and at two depths in lightly grazed saltbush rangeland are presented in Table 5 . The 
Table 5. The rate of production $(\mu \mathrm{g})$ of nitrate $\left(\mathrm{NO}_{3}\right)$ per gram total soil nitrogen per ten hours by soils from two sites within saltbush rangeland grazed at two intensities, at two depths in lightly grazed saltbush rangeland.

\begin{tabular}{|c|c|c|c|c|c|}
\hline $\begin{array}{l}\text { Grazing } \\
\text { intensity }\end{array}$ & Depth & Bush & Interbush & Difference & $\begin{array}{c}\text { Significance } \\
\text { of } \\
\text { difference }\end{array}$ \\
\hline Lightly grazed ${ }^{1}$ & $0-7.5 \mathrm{~cm}$ & 740 & 140 & 600 & $* * 3$ \\
\hline Heavily grazed ${ }^{2}$ & $0-7.5 \mathrm{~cm}$ & 600 & 170 & 430 & * * \\
\hline Difference & & 140 & 30 & & \\
\hline Signif. of Difference & & N.S. & N.S. & & \\
\hline Lightly grazed 1 & $0-7.5 \mathrm{~cm}$ & 470 & 320 & 150 & $* *$ \\
\hline Lightly grazed ${ }^{1}$ & $7.5-15 \mathrm{~cm}$ & 300 & 180 & 120 & N.S. \\
\hline Difference & & 170 & 140 & & \\
\hline Signif. of Difference & & $* *$ & N.S. & & \\
\hline
\end{tabular}

1 Experimental areas stocked at 0.6 sheep per hectare for 3 years.

2 Experimental areas stocked at 2.5 sheep per hectare for 3 ycars.

$3 * *=\mathbf{P}<0.01$.

rate of nitrification was consistently greater for soils from sites associated with saltbush than for interbush areas. This effect was confined to the $0-7.5 \mathrm{~cm}$ soil horizon. The rate of nitrification decreased with depth for soils under saltbush, but not for soil from the interbush area.

In order to get some indication of the effect of elimination ol saltbushes on the soil environment, particularly for decomposers, temperatures were measured at 3:00 p.m. on February 5, 1970, when the ambient air temperature was $40 \mathrm{C}$. The temperature of the soil associated with saltbush in the lightly grazed and heavily grazed areas was $43 \mathrm{C}$ and $59 \mathrm{C}$ respectively at $1.3 \mathrm{~cm}$, and $36 \mathrm{C}$ and $46 \mathrm{C}$ respectively at $5 \mathrm{~cm}$. The temperature of the interbush area for both stocking rates was $46 \mathrm{C}$ at $1.3 \mathrm{~cm}$.

\section{Discussion}

The greater uptake of oxygen by soils associated with saltbush than by soils from the interbush area (Figs. 1 and 2) correspond with the contrasting amounts of plant material and litter at the two sites within the plant community (Table 1). Leaf fall from saltbush is substantial during the summer and autumn. The annual contribution to litter from the bushes can be much greater than the amount of vegetative material on the bushes when they are in their period of maximum production (Charley, 1959).

Under field conditions, lack of moisture would be the major factor limiting the duration of decomposition of organic residues. Nevertheless, the rapid decomposition rate, as indicated in Figure 1 and Table 3 , would be expected when appropriate moisture conditions prevail, and this would avoid any long term massive accumulation of litter and organic matter.

The marked differences in oxygen uptake were restricted to the $0-7.5 \mathrm{~cm}$ soil horizon (Fig. 2). The lesser amount of oxygen taken up by the $7.5-15 \mathrm{~cm}$ soil horizon was probably due to a smaller supply of organic carbon. Charley and Cowling (1968) described the notable concentration of organic matter and associated nutrients near the surface of soils in arid and semiarid regions.

Soil associated with saltbush produced at least twice as much nitrate as soils from the interbush area. This difference in nitrate production is greater than the difference in total nitrogen in the soils from the two sites within the plant community (Table 2). Moreover, the greater rate of nitrification from soils collected from under saltbush indicate that the surface soil has a greater potential capacity to supply mineral nitrogen than soils from interbush areas (Table 5). Much of the soil organic matter in the site associated with saltbush would be derived from saltbush, and it appears that organic residues from this plant probably have a greater ratc of nitrification than organic residues derived principally from annual composites in the interbush area. Significant response by native vegetation to nitrogen applied to Billabong clay has been obtained by Tupper (1968). Some plant species are common to both sites within the plant community and preliminary investigations have shown a differential concentration of nitrogen in these plants in accordance with the differing potential capacity to supply mineral nitrogen by the underlying surface soil (Rixon, unpublished data).

The different nitrification rates were restricted to the surface soil, as were the differing rates of oxygen uptake (Fig. 2). Nevertheless, these differences are important, particularly where there is an overall nitrogen deficiency, and need to be taken into account in considering nitrogen cycling and nitrogen balance studies in low shrub communities in semiarid rangeland.

Grazing intensity did not affect the rate of nitrification within the plant community. Thus, alternating areas with contrasting capacities to supply mineral nitrogen would prevail, at least for some years, after the elimination of the saltbushes.

\section{References}

Birch, J. W., and Margaret Melville. 1969. An electrolytic respirometer for measuring oxygen uptake in soils. J. Soil Sci. 20:101-110.

Branson, F. A., R. F. Miller, And I. S. McQueEn. 1967. Geographic distribution of salt desert shrubs in the United States. J. Range Manage. 20:287-296.

Bremner, J. M., and D. R. Keeney. 1965. Steam distillation methods for determination of ammonium, nitrate, and nitrite. Anal. Chim. Acta 32:485-495.

Charley, J. L. 1959. Soil salinityvegetation patterns in western New 
South Wales and their modification by overgrazing. Ph.D. Thesis, University of New England, Armidale, New South Wales, Australia.

Charley, J. L., and S. W. Cowling. 1968. Changes in soil nutrient status resulting from overgrazing and their consequences in plant communities of semi-arid areas. Proc. Ecol. Soc. Aust. 3:28-38.

Osborn, T. G. B., J. G. WoOd, And T. B. Paltridge. 1935. On the growth and reaction to grazing of the perennial saltbush, Atriplex vesicarium, an ecological study of the biotic factor. Proc. Linn. Soc. N.S.W. 57:377402.

PIPeR, C. S. 1942. Soil and plant analysis. University of Adelaide, Australia.

Rixon, A. J. 1968. Oxygen uptake and nitrification at various moisture levels by soils and mats from irrigated pastures. J. Soil Sci. 19:56-66.

Ross, M. A. 1969. An integrated approach to the ecology of arid Australia. Proc. Ecol. Soc. Aust. 4:67-81. Sмiтh, R. 1945. Soils of the Berri- quin Irrigation District, N.S.W. Bull. of Council for Sci. and Ind. Res., Melbourne, Australia. No. 189.

Tupper, G. 1968. Annual Report, Division of Plant Industry, Commonwealth Sci. and Ind. Res. Organ., Australia.

Wilson, A. D., J. H. Leigh, and W. E. Mulfam. 1969. A study of Merino sheep grazing a bladder saltbush (Atriplex vesicaria) cottonbush (Kochia aphylla) community on the Riverine Plain. Aust. J. Agr. Res. 20: 1123-1137. 